\title{
Hippoboscid flies (Diptera: Hippoboscidae) on birds of prey in the Atlantic Forest, Minas Gerais, Brazil
}

\author{
Hipoboscídeos (Diptera: Hippoboscidae) em aves de rapina da Mata Atlântica, \\ Minas Gerais, Brasil
}

Glauber Thiago Martins Barino1* (D); Roberto Júnio Pedroso Dias; Gustavo Graciolli²

${ }^{1}$ Departamento de Zoologia, Instituto de Ciências Biológicas, Universidade Federal de Juiz de Fora - UFJF, Juiz de Fora, MG, Brasil ${ }^{2}$ Departamento de Biologia, Universidade Federal do Mato Grosso do Sul - UFMS, Campo Grande, MS, Brasil

How to cite: Barino GTM, Dias RJP, Graciolli G. Hippoboscid flies (Diptera: Hippoboscidae) on birds of prey in the Atlantic Forest, Minas Gerais, Brazil. Braz J Vet Parasitol 2021; 30(1): e016720. https://doi.org/10.1590/S1984-296120201082

\begin{abstract}
Hippoboscid flies are potential ectoparasites of several avian orders, including birds of prey, a group formed by the orders Falconiformes, Strigiformes, Cathartiformes and Accipitriformes. In this study, we evaluated 155 birds of prey that were brought to the Wildlife Rehabilitation Center of Juiz de Fora, Minas Gerais, Brazil, between the years 2016 and 2019. Two species of hippoboscid flies (Ornithoctona erythrocephala and Icosta americana) were found in five species of birds of prey (Megascops choliba, Asio stygius, Athene cunicularia, Asio clamator and Caracara plancus). The average intensity found was 1.4 hippoboscids/bird and Megascops choliba (tropical screech-owl) was the most parasitized bird. This is the first record of parasitism of Asio stygius (stygian owl) by Ornithoctona erythrocephala in Brazil and of Athene cunicularia (burrowing owl) and Asio clamator (striped owl) by Icosta americana. Ornithoctona erythrocephala is recorded here for the first time infesting birds of prey in the state of Minas Gerais, Brazil.
\end{abstract}

Keywords: Ornithoctona erythrocephala, Icosta americana, geographical distribution, parasitism, hippoboscids flies.

\section{Resumo}

Moscas hipoboscídeas são ectoparasitos potenciais de diversas ordens aviárias, incluindo as aves de rapina, grupo formado pelas ordens Falconiformes, Strigiformes, Cathartiformes e Accipitriformes. Neste estudo foram avaliadas 155 aves de rapina que chegaram ao Centro de Triagem de Animais Silvestres de Juiz de Fora, Minas Gerais, Brasil, entre os anos 2016 e 2019. Foram encontradas duas espécies de hipoboscídeos (Ornithoctona erythrocephala e Icosta americana) em cinco espécies de aves de rapina (Megascops choliba, Asio stygius, Athene cunicularia, Asio clamator e Caracara plancus). A intensidade média encontrada foi de 1,4 hipoboscídeo/ave e a espécie de coruja Megascops choliba (corujinha-do-mato) foi a mais parasitada. Este é o primeiro registro do parasitismo da coruja Asio stygius (mocho-diabo) por Ornithoctona erythrocephala, em território brasileiro, e das corujas Athene cunicularia (coruja-buraqueira) e Asio clamator (coruja-orelhuda), sendo parasitadas por Icosta americana. Ornithoctona erythrocephala é aqui registrada pela primeira vez infestando aves de rapina no estado de Minas Gerais, Brasil.

Palavras-chave: Ornithoctona erythrocephala, Icosta americana, distribuição geográfica, parasitismo, moscas hipoboscídeos. 
Flies of the family Hippoboscidae (Diptera: Hippoboscoidea) are ectoparasites that infest birds and mammals and establish an obligate parasitic relationship (Wood, 2010). These flies are viviparous and deposit their mature larvae in the soil or substrate in the bird's nest or inside the coat of mammals such as cervids and sheep, in which they turn into pupae and then emerge as adults (Wood, 2010). Adult hippoboscid flies have a body that is generally wide and flattened dorsoventrally, small head, reduced or absent ocelots and strong claws that help them to become attached to their host. These flies are usually winged, but with limited flying ability, and there are even some species that do not fly, with vestigial wings or even without the presence of wings (Wood, 2010). The family Hippoboscidae is composed of three subfamilies: Ornithomyiinae, Lipopteninae and Hippoboscinae, with about 213 species distributed in 21 genera. Many of these species are bird ectoparasites (Dick, 2006; Wood, 2010). In Brazil, 30 species of flies of this family have been recorded in 10 genera (Bequaert, 1955; Graciolli, 2020), parasitizing a wide diversity of species of birds and mammals.

Birds of prey are a paraphyletic group composed of the orders Falconiformes, Strigiformes, Cathartiformes and Accipitriformes (Prum et al., 2015). They are highly susceptible to infestations caused by hippoboscid flies. In birds of the family Falconidae (Falconiformes), for example, several species of hippoboscid flies have been recorded, such as Ornithoctona erythrocephala, Ornithophila gestroi, Ornithomya avicularia, Ornithomya chloropus, Icosta nigra, Phthona leptoptera, Phthona modesta, Phthona nigrita and Pseudolynchia canariensis (Maa, 1969; Moreira et al., 2019). However, for the other orders of birds of prey, little information on this parasitic relationship exists. Moreover, the infestation data available may not include the geographical distribution of the ectoparasite. This knowledge gap remains to be filled through new studies.

In addition to the obligate parasitic relationship with birds, hippoboscid flies play an important role in the transmission of various diseases caused by different pathogens. Among these pathogens are the West Nile virus as found in specimens of Icosta americana that parasitize birds of prey in Canada and the United States (Gancz et al., 2004; Farajollahi et al., 2005); and Haemoproteus syrnii, a parasitic hemosporid that occurs in the fly Ornithomyia sp., which parasitizes the tawny owl (Strix aluco), an owl of the Strigidae family that is found in Europe, Asia and Africa (Karadjian et al., 2013).

Thus, in the present study, we report new occurrences of hippoboscid flies parasitizing birds of prey in the Atlantic Forest of southeastern Brazil that were received by the Wildlife Rehabilitation Center of Juiz de Fora (CETAS JF), state of Minas Gerais.

During the years 2016 to 2019, a total of 155 birds of prey belonging to four orders, five families, 20 genera and 23 species were brought to the CETAS Juiz de Fora (geographic coordinates $21^{\circ} 47^{\prime} 40.4^{\prime \prime} \mathrm{S} ; 43^{\circ} 22^{\prime} 52.73^{\prime \prime} \mathrm{W}$ ), which receives birds from the Zona da Mata region of Minas Gerais, through voluntary handover by members of the general public, or through collection or apprehension by environmental agencies. The Wildlife Rehabilitation Center has the function of rehabilitating and reintroducing these animals into the wild, or guiding them to wildlife management categories, such as zoos, maintenance facilities or scientific and commercial breeders. Immediately after the birds' arrival at CETAS, they were identified following the taxonomic classification of Sick (1997) and were then thoroughly examined for their clinical condition and the presence of hippoboscid flies. Manual collection of ectoparasites was carried out through the inspection of the coverts, remiges and retrices, the wing feathers, tail, head and body, following the guidelines of Arzua \& Valim (2010). The final confirmation of the absence of hippoboscid flies was made by blowing the plumage to expose the skin in the covered areas. The diptera were collected with tweezers in order to limit their locomotion, but without damaging any part of their body, and placed in duly identified plastic containers containing $70^{\circ} \mathrm{GL}$ ethanol until the time of identification. The species were identified under a stereoscopic microscope using the identification key of Graciolli \& Carvalho (2003).

To describe the prevalence and intensity of these dipterans in their hosts, the parasitological indices established by Bush et al. (1997) were used. The prevalence was calculated by dividing the number of parasited hosts by the number of hosts examined, being performed for each bird species individually, and here given as a percentage. The mean intensity was calculated by dividing the total number of ectoparasites found $(n=7)$ by the total number of parasited hosts $(n=5)$.

Seven specimens of dipterans were found in five species of birds of prey. Megascops choliba (tropical screech-owl) was the most parasitized, with two hippoboscid flies, and the other four bird species had only one hippoboscid fly per individual. Thus, the total average intensity of parasitism was 1.4 hippoboscids/bird. The prevalence of infestation by avian species was thus found: Asio clamator (7.14\%), Asio stygius (50\%), Athene cunicularia (20\%), Megascops choliba (3.03\%) and Caracara plancus (5.26\%). The clinical examination of the birds received was performed by the team of veterinarians of the CETAS Juiz de Fora, and no direct relationship was found between the amount of hippoboscid flies and the clinical condition of the animal. The bird species examined and the ectoparasites and prevalence found are described in Table 1. 
Table 1. Prevalence of hippoboscid flies parasitizing birds of prey received by the Wildlife Rehabilitation Center of Juiz de Fora (CETAS JF), state of Minas Gerais, Brazil, during the years 2016 to 2019.

\begin{tabular}{|c|c|c|c|}
\hline $\begin{array}{c}\text { Birds of prey } \\
\text { Order, Families and Species }\end{array}$ & Number of examined birds & Species of hippoboscid flies & $\begin{array}{l}\text { Prevalence in each avian } \\
\text { species* }\end{array}$ \\
\hline \multicolumn{4}{|l|}{ Accipitriformes } \\
\hline \multicolumn{4}{|l|}{ Accipitridae } \\
\hline Buteo brachyurus & 2 & - & - \\
\hline Elanoides forficatus & 1 & - & - \\
\hline Geranoaetus albicaudatus & 9 & - & - \\
\hline Geranoaetus melanoleucus & 1 & - & - \\
\hline Heterospizias meridionalis & 1 & - & - \\
\hline Ictinia plumbea & 1 & - & - \\
\hline Rupornis magnirostris & 10 & - & - \\
\hline Spizaetus tyrannus & 1 & - & - \\
\hline \multicolumn{4}{|l|}{ Cathartiformes } \\
\hline \multicolumn{4}{|l|}{ Cathartidae } \\
\hline Cathartes burrovianus & 1 & - & - \\
\hline Coragyps atratus & 15 & - & - \\
\hline \multicolumn{4}{|l|}{ Falconiformes } \\
\hline \multicolumn{4}{|l|}{ Falconidae } \\
\hline Caracara plancus & 19 & Ornithoctona erythrocephala & $5.26 \%(1)$ \\
\hline Falco sparverius & 7 & - & - \\
\hline Milvago chimachima & 7 & - & - \\
\hline \multicolumn{4}{|l|}{ Strigiformes } \\
\hline \multicolumn{4}{|l|}{ Strigidae } \\
\hline Asio clamator & 14 & Icosta americana & $7.14 \%(1)$ \\
\hline Asio stygius & 2 & Ornithoctona erythrocephala & $50.0 \%(1)$ \\
\hline Athene cunicularia & 5 & Icosta americana & $20.0 \%(1)$ \\
\hline Bubo virginianus & 3 & - & - \\
\hline Glaucidium brasilianum & 6 & - & - \\
\hline Megascops choliba & 33 & Icosta americana & $3.03 \%(2)$ \\
\hline Pulsatrix koeniswaldiana & 5 & - & - \\
\hline Strix huhula & 4 & - & - \\
\hline Strix virgata & 1 & - & - \\
\hline \multicolumn{4}{|l|}{ Tytonidae } \\
\hline Tyto furcata & 7 & - & - \\
\hline Total & 155 & & \\
\hline
\end{tabular}

*The number in the parenthesis indicates the quantitative of flies found in that host species.

Although hippoboscid dipterans are not exclusively ectoparasites of birds of prey, and may infest several avian orders, birds of prey seem to be frequent hosts of these dipterans. Vaz \& Teixeira (2016) also studied hippoboscid flies and found that $76.74 \%$ of them parasitized birds in the orders that comprise birds of prey, i.e. that hippoboscids were highly prevalent in this group of birds. Our findings corroborate these data through showing that several species of different orders of birds of prey are infested by these ectoparasites. 
Specifically, in relation to hippoboscid flies in owls (order Strigiformes), Graciolli \& Bispo (2005) found a prevalence of $16.7 \%$ and Vaz \& Teixeira (2016) found $17.6 \%$, i.e. well above the average prevalence for this order found in our study (3.22\%). This difference in prevalence may be related to the location and availability of hosts, the bird species and climatic conditions (Young et al., 1993; Senar et al., 1994). According to Lloyd (2002), hippoboscid flies may also present specificity of parasitism for certain hosts, such that levels of parasitism appear to vary according to the bird species. However, this specificity was not found in our study, or in other studies on birds of prey (Graciolli \& Carvalho, 2003; Vaz \& Teixeira, 2016).

The two species of dipteran flies found in the present study (Figures 1 and 2) have wide distribution in the Americas. Ornithoctona erythrocephala has been recorded parasitizing more than 76 genera of birds in 25 families of 14 orders, in more than 25 countries (Maa, 1969); while Icosta americana has been recorded parasitizing more than 33 genera of birds in 14 families of 8 orders, in more than 13 countries (Maa, 1969).

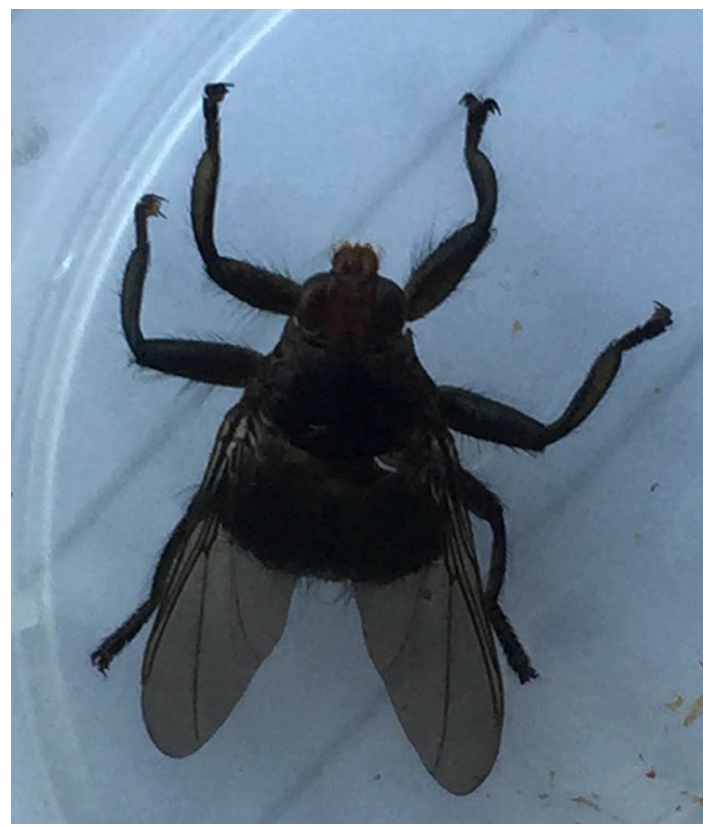

Figure 1. Ornithoctona erythrocephala found in Southern Caracara (Caracara plancus).

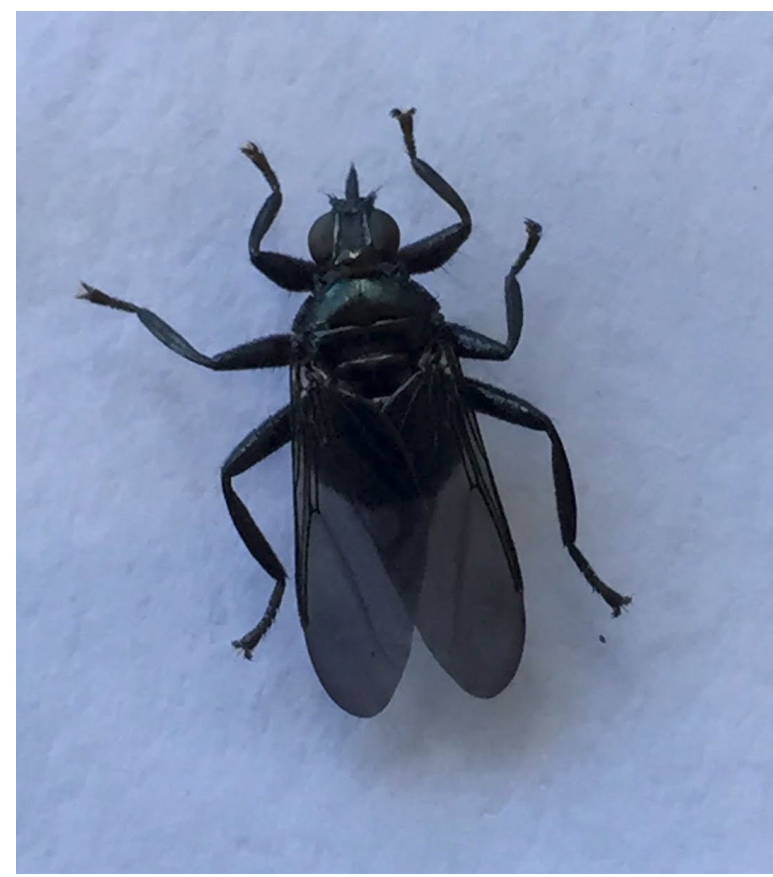

Figure 2. Icosta americana found in Tropical Screech-Owl (Megascops choliba). 
Our study provides the first report of parasitism by Ornithoctona erythrocephala in the bird of prey Asio stygius (stygian owl) in Brazil. Previously, this association had only been reported in Cuba (Bequaert, 1954). There have also been reports of parasitism by Icosta americana, Icosta rufiventris and Ornithoica vicina in this bird species (Moreira et al., 2019; Vaz \& Teixeira, 2016).

Regarding the species Athene cunicularia (burrowing owl) and Asio clamator (striped owl), parasitism by Icosta rufiventris and Ornithoica vicina had previously been reported (Vaz \& Teixeira, 2016). Here, we additionally report parasitism by Icosta americana in these two species.

Moreira et al. (2019) and Vaz \& Teixeira (2016) had reported the presence of Ornithoctona erythrocephala infesting Caracara plancus (southern caracara), and this was also found in our study. This bird species appears to be quite susceptible to this ectoparasite.

Concerning the geographical distribution of hippoboscid flies, Icosta americana had already been recorded in the state of Minas Gerais (where the present study was conducted), and in the states of Goiás, Paraná, Rio Grande do Sul, Santa Catarina and São Paulo (Graciolli \& Carvalho, 2003). In addition to Minas Gerais, I. americana had already been recorded parasitizing M. choliba in the states of Paraná and São Paulo (Bequaert, 1955; Graciolli \& Carvalho, 2003). Ornithoctona erythrocephala was recorded in the present study for the first time in the state of Minas Gerais. Previously, this species had been recorded in the states of Mato Grosso, Mato Grosso do Sul, São Paulo, Paraná, Santa Catarina and Rio Grande do Sul (Graciolli \& Carvalho, 2003, Graciolli et al., 2017).

It is worth noting that these ectoparasites can exert a series of effects on their hosts, and can affect the temporal and spatial dynamics of natural populations and bird communities (Leite et al., 2013). Thus, checking for ectoparasites in birds arriving at screening centers in Brazil should be incorporated into the daily routine of animal management, since the presence of hippoboscid flies may be related to diseases that might cause pathological changes in birds and, in more serious cases, lead them to death. Identifying the species of dipterans that occur in the region and parasitize birds of prey may be fundamental for the management, treatment and correct reintroduction of these birds into the wild.

\section{Acknowledgements}

We thank the Instituto Estadual de Florestas de Minas Gerais (IEF) and the Instituto Brasileiro de Meio Ambiente e Recursos Naturais Renováveis (IBAMA) for permitting collection of the birds in this study (authorizations numbers 033/2017/IEF and 3/2017/IBAMA). We would like to thank the Fundação de Amparo à Pesquisa do Estado de Minas Gerais (FAPEMIG) (project numbers FAPEMIG/PPM/2016 and PPM-00734-16) and the Coordenação de Aperfeiçoamento de Pessoal de Nível Superior (CAPES) (2011 Announcement for Basic Parasitology), for their financial support.

\section{References}

Arzua M, Valim MP. Bases para o estudo qualitativo e quantitativo de ectoparasitos em aves. In: Matter SV, Straube FC, Accordi IA, Piacentini VQ, Cândido-Jr JF. Ornitologia e conservação: ciência aplicada, técnicas de pesquisa e levantamento. Rio de Janeiro: Technical Books Editora; 2010. p. 349-365.

Bequaert J. The Hippoboscidae or louse-flies (Diptera) of mammals and birds. Part II. Taxonomy, evolution and revision of American genera and species. Ent Am 1954; 34: 1-232.

Bequaert J. The Hippoboscidae or louse-flies (Diptera) of mammals and birds. Part II. Taxonomy, evolution and revision of American genera and species. Ent Am 1955; 35: 233-416.

Bush A, Laffery KD, Lotz JM, Shostak AW. Parasitology meets ecology on its own terms: Margolis et al. revisited. J Parasitol 1997; 83(4): 575-583. http://dx.doi.org/10.7939/R3J38KV04. PMid:9267395.

Dick CW. Checklist of world Hippoboscidae (Diptera: Hippoboscoidea). Chicago: Department of Zoology, Field Museum of Natural History; 2006.

Farajollahi A, Crans WJ, Nickerson D, Bryant P, Wolf B, Glaser A, et al. Detection of West Nile virus RNA from the louse fly Icosta americana (Diptera: hippoboscidae). J Am Mosq Control Assoc 2005; 21(4): 474-476. http://dx.doi.org/10.2987/8756-971X(2006)2 1[474:DOWNVR]2.0.CO;2. PMid:16506578.

Gancz AY, Barker IK, Lindsay R, Dibernardo A, McKeever K, Hunter B. West Nile Virus Outbreak in North American Owls, Ontario, 2002. Emerg Infect Dis 2004; 10(12): 2135-2142. http://dx.doi.org/10.3201/eid1012.040167. PMid:15663850. 
Graciolli G, Bispo AA. Hippoboscidae (Diptera) ectoparasitos sobre seis espécies de corujas (Strigiformes) no estado do Paraná, Sul do Brasil. Rev Bras Ornitol 2005; 13(2): 181-182.

Graciolli G, Carvalho CJB. Hippoboscidae (Diptera, Hippoboscoidea) no Estado do Paraná, Brasil: chaves de identificação, hospedeiros e distribuição geográfica. Rev Bras Zoo/ 2003; 20(4): 667-674. http://dx.doi.org/10.1590/S0101-81752003000400019.

Graciolli G, Carvalho LFAC, Eriksson AF, Silva CL, Alcântara DMC. Lista das espécies de Hippoboscoidea (Diptera) no estado de Mato Grosso do Sul, Brasil. Iheringia Ser Zool 2017; 107: e2017137. http://dx.doi.org/10.1590/1678-4766e2017137.

Graciolli G. Catálogo Taxonômico da Fauna do Brasil (Hippoboscidae) - PNUD [online]. 2020 [cited 2020 May 6]. Available from: http://fauna.jbrj.gov.br/fauna/faunadobrasil/1981

Karadjian G, Puech MP, Duval L, Chavatte JM, Snounou G, Landau I. Haemoproteus syrnii in Strix aluco from France: morphology, stages of sporogony in hippoboscid fly, molecular characterization and discussion on the identification of Haemoproteus species. Parasite 2013; 20: 32. http://dx.doi.org/10.1051/parasite/2013031. PMid:24029169.

Leite YFC, Pinheiro RT, Braga EM. Prevalência de Hemosporideos em três localidades do Estado do Tocantins, Brasil. Ornithologia 2013; 6(1): 1-13.

Lloyd JE. Louse flies, keds, and related flies (Hippoboscoidea). In: Mullen G, Durden L. Medical and Veterinary Entomology. San Diego: Academic Press; 2002. p. 349-362.

Maa TC. A revised checklist and concise host index of Hippoboscidae (Diptera). Pacific Insects Monograph 1969; 20: 261 -299.

Moreira RF, Farezin LC, Souza UA, Silva BZ, Amorim DB, Girotto-Soares A, et al. Pupipara (Diptera, Hippoboscidae) in wild birds attended at a rehabilitation center in southern Brazil. Rev Bras Parasitol Vet 2019; 28(2): 330-332. http://dx.doi.org/10.1590/ S1984-29612019004. PMid:31166378.

Prum RO, Berv JS, Dornburg A, Field DJ, Townsend JP, Lemmon EM, et al. A comprehensive phylogeny of birds (Aves) using targeted next-generation DNA sequencing. Nature 2015; 526(7574): 569-573. http://dx.doi.org/10.1038/nature15697. PMid:26444237.

Senar JC, Copete JL, Domenech J, Walter GV. Prevalence of louse-flies Diptera, Hippoboscidae parasiting a cardueline finch and its effect on body condition. Ardea 1994; 82(1): 157-160.

Sick H. Ornitologia brasileira. Rio de Janeiro: Editora Nova Fronteira; 1997.

Vaz FF, Teixeira VN. New records of three hippoboscid species on newly captured birds from nature in Paraná, Brazil. Rev Bras Parasitol Vet 2016; 25(4): 501-503. http://dx.doi.org/10.1590/S1984-29612016056. PMid:27737369.

Wood MW. Hippoboscidae. In: Brown BV, Borkent A, Cumming JM, Wood DM, Woodley NE, Zumbado MA. Manual of Central American Diptera. 2nd ed. Ottawa: NRC Research Press; 2010. p. 1241-1248.

Young KE, Franklin AB, Ward JP. Infestation of northern spotted owls by hippoboscid (Diptera) flies in Northwestern California. J Wildl Dis 1993; 29(2): 278-283. http://dx.doi.org/10.7589/0090-3558-29.2.278. PMid:8487378. 